Supporting information

\title{
Studies toward the Total Synthesis of Gambieric Acids, Potent Antifungal Polycyclic Ethers: Convergent Synthesis of the CDEFG Ring System
}

\author{
Kazushi Sato and Makoto Sasaki* \\ Laboratory of Biostructural Chemistry, Graduate School of Life Sciences, Tohoku University \\ Tsutsumidori-Amamiya, Aoba-ku, Sendai 981-8555, Japan \\ E-mail: masasaki@bios.tohoku.ac.jp
}


General Methods. All reactions sensitive to air or moisture were carried out in oven dried glassware under an argon atmosphere unless otherwise noted. Anhydrous dichloromethane $\left(\mathrm{CH}_{2} \mathrm{Cl}_{2}\right)$, acetonitrile $\left(\mathrm{CH}_{3} \mathrm{CN}\right)$ and tetrahydrofurane (THF) were purchased from Kanto Chemical Co., Inc., Wako Pure Chemical Industries, Ltd. or Aldrich Chemical Co. and used without further drying. Trimethylsilyl chloride (TMSCl) was distilled from calcium hydride. All other reagents were used as supplied unless otherwise stated. Analytical thin-layer chromatography (TLC) was performed using E. Merck silica gel $60 \mathrm{~F}_{254}$ pre-coated plates (0.25-mm thickness). For column chromatography Fuji Silysia silica gel BW-300 (200-400 mesh) was used. Optical rotations were recorded on a JASCO DIP-370 digital polarimeter. ${ }^{1} \mathrm{H}$ and ${ }^{13} \mathrm{C}$ NMR spectora were recorded on a Varian Unity INOVA 600 or INOVA 500 spectrometer. Chemical shifts are reported in ppm from tetramethylsilane with refernce to internal residual solvent $\left[{ }^{1} \mathrm{H} \mathrm{NMR}, \mathrm{CHCl}_{3}\right.$ (7.24), $\mathrm{C}_{6} \mathrm{HD}_{5}$ (7.15), $\mathrm{CHD}_{2} \mathrm{OD}(3.30) ;{ }^{13} \mathrm{C}$ $\mathrm{NMR}, \mathrm{CDCl}_{3}$ (77.0), $\mathrm{C}_{6} \mathrm{D}_{6}$ (128.0), $\mathrm{CD}_{3} \mathrm{OD}$ (49.0)]. The following addreviations are used to designate the multiplicities: $\mathrm{s}=$ singlet, $\mathrm{d}=$ doublet, $\mathrm{t}=$ triplet, $\mathrm{q}=$ quartet, $\mathrm{m}=$ multiplet, $\mathrm{br}=$ broad peak. High-resolution mass spectra (HRMS) were record on a JEOL JMS-700 mass spectrometer under fast atom bombardment conditions using $m$-nitrobenzyl alcohol (NBA) or glycerol as a matrix.

\section{Experimental Procedures}

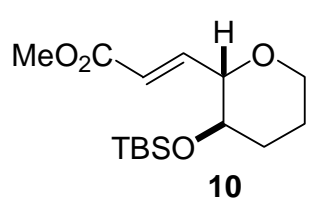

Enoate 10. To a solution of alcohol $9^{1}(0.75 \mathrm{~g}, 5.85 \mathrm{mmol})$ in DMF $(12 \mathrm{~mL})$ at $0{ }^{\circ} \mathrm{C}$ were added imidazole (1.24 g, 18.3mmol), DMAP (70.9 mg, $0.58 \mathrm{mmol})$, and TBSCl (2.20 g, $14.6 \mathrm{mmol})$. The resultant mixture was stirred at room temperature for $5 \mathrm{~h}$. The reaction mixture was quenched with saturated aqueous $\mathrm{NH}_{4} \mathrm{Cl}$ and diluted with ether. The organic layer was washed with brine, dried over $\mathrm{Na}_{2} \mathrm{SO}_{4}$, filtered and concentrated under reduced pressure. Purification by column chromatography on silica gel (20\% ethyl acetate/hexanes) afforded TBS ether (1.28 g, 90\%), which was used directly in subsequent reaction.

To a solution of the above TBS ether $(1.28 \mathrm{~g}, 5.27 \mathrm{mmol})$ in $\mathrm{THF} / \mathrm{H}_{2} \mathrm{O}(1: 1, \mathrm{v} / \mathrm{v}, 20 \mathrm{~mL})$ were added $N$-methylmorpholine (50 wt $\%$ in water, $2.4 \mathrm{~mL}, 10.5 \mathrm{mmol})$ and $\mathrm{OsO}_{4}(0.039 \mathrm{M}$ in $t$ - $\mathrm{BuOH}$, $6.67 \mathrm{~mL}, 0.26 \mathrm{mmol})$. The resultant mixture was stirred at room temperature for $23 \mathrm{~h} . \mathrm{NaIO}_{4}(3.38 \mathrm{~g}$, $15.8 \mathrm{mmol}$ ) was added and the mixture was stirred at room temperature for further $8 \mathrm{~h}$. The reaction mixture was diluted with ethyl acetate, washed with $\mathrm{H}_{2} \mathrm{O}$, saturated aqueous $\mathrm{Na}_{2} \mathrm{SO}_{3}$ and brine. The organic layer was dried over $\mathrm{Na}_{2} \mathrm{SO}_{4}$, filtered and concentrated under reduced pressure. The crude aldehyde was used directly in the subsequent reaction without purification.

(1) Nicolaou, K. C.; Prasad, C. V. C.; Somers, P. K.; Hwang, C.-K. J. Am. Chem. Soc. 1989, 111, 5330-5334. 
To a solution the above aldehyde in $\mathrm{CH}_{2} \mathrm{Cl}_{2}$ (53 $\left.\mathrm{mL}\right)$ was added methyl (triphenylphosphoraylidene)acetate $(2.30 \mathrm{~g}, 6.85 \mathrm{mmol})$. The resultant mixture was stirred at room temperature for $12 \mathrm{~h}$. The mixture was diluted with ether and washed with brine. The organic layer was dried over $\mathrm{Na}_{2} \mathrm{SO}_{4}$, filtered and concentrated under reduced pressure. Purification by column chromatography on silica gel (30\% ethyl acetate/hexanes) afforded enoate $\mathbf{1 0}(1.44 \mathrm{~g}, 90 \%$ for the two steps) as a colorless oil: $[\alpha]^{20}{ }_{\mathrm{D}}-40.8\left(c 0.81, \mathrm{CHCl}_{3}\right) ;{ }^{1} \mathrm{H} \mathrm{NMR}\left(500 \mathrm{MHz}, \mathrm{CDCl}_{3}\right) \delta 7.10(\mathrm{dd}, J=$ $15.5,4.5 \mathrm{~Hz}, 1 \mathrm{H}), 6.03(\mathrm{dd}, J=15.5,1.5 \mathrm{~Hz}, 1 \mathrm{H}), 3.95-3.92(\mathrm{~m}, 1 \mathrm{H}), 3.71(\mathrm{~s}, 3 \mathrm{H}), 3.68-3.65(\mathrm{~m}, 1 \mathrm{H})$, 3.39-3.34 (m, 1H), 3.32-3.27 (m, 1H), 2.04-2.01 (m, 1H), 1.68-1.64 (m, 2H), 1.55-1.47 (m, 1H), 0.86 (s, 9H), 0.02 (s, 6H); ${ }^{13} \mathrm{C}$ NMR (125 MHz, $\left.\mathrm{CDCl}_{3}\right) \delta 167.0,146.5,120.4,81.1,71.2,67.6$, 51.5, 33.8, 25.7 (x 3), 25.3, 17.9, -4.3, -4.9; HRMS (FAB) calcd for $\mathrm{C}_{15} \mathrm{H}_{28} \mathrm{O}_{4} \mathrm{SiNa}\left[(\mathrm{M}+\mathrm{Na})^{+}\right]$ 323.1655 , found 323.1660 .

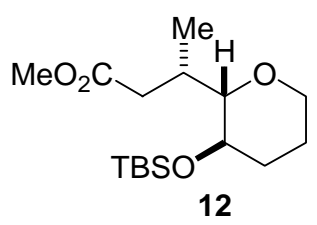

Ester 12. To a solution of $i$-propylsalicylaldimine copper(II) complex $\mathbf{1 1}^{2}(5 \mathrm{mg}, 1.28 \mu \mathrm{mol})$ and TMSCl $(0.49 \mathrm{~mL}, 3.84 \mathrm{mmol})$ in THF $(3.2 \mathrm{~mL})$ at $-45^{\circ} \mathrm{C}$ was added enoate $\mathbf{1 0}(0.39 \mathrm{~g}, 1.28 \mathrm{mmol})$ in THF (3.2 mL). Methylmagnesium bromide (3.0 M in ether, $0.64 \mathrm{~mL}, 1.92 \mathrm{mmol}$ ) was added and the resultant mixture was stirred at $-45{ }^{\circ} \mathrm{C}$ for $1.5 \mathrm{~h}$. The reaction mixture was quenched with $1 \mathrm{M}$ aqueous $\mathrm{HCl}$ and diluted with ether. The organic layer was washed with saturated aqueous $\mathrm{NaHCO}_{3}$ and brine, dried over $\mathrm{Na}_{2} \mathrm{SO}_{4}$, filtered and concentrated under reduced pressure. Purification by column chromatography on silica gel (30\% ethyl acetate/hexanes) afforded ester $\mathbf{1 2}(0.37 \mathrm{~g}, 92 \%)$ as a colorless oil: $[\alpha]^{20}{ }_{\mathrm{D}}-2.12\left(c 0.24, \mathrm{CHCl}_{3}\right) ;{ }^{1} \mathrm{H}$ NMR $\left(500 \mathrm{MHz}, \mathrm{CDCl}_{3}\right) \delta 3.84-3.82(\mathrm{~m}, 1 \mathrm{H}), 3.63(\mathrm{~s}$, $3 \mathrm{H}), 3.38(\mathrm{ddd}, J=10.0,10.0,4.5 \mathrm{~Hz}, 1 \mathrm{H}), 3.25(\mathrm{~m}, 1 \mathrm{H}), 2.93-2.91(\mathrm{~m}, 1 \mathrm{H}), 2.44-2.37(\mathrm{~m}, 2 \mathrm{H}), 2.12$ $(\mathrm{dd}, J=15.0,10.5 \mathrm{~Hz}, 1 \mathrm{H}), 2.02-1.99(\mathrm{~m}, 1 \mathrm{H}), 1.59-1.51(\mathrm{~m}, 2 \mathrm{H}), 1.43-1.35(\mathrm{~m}, 1 \mathrm{H}), 1.02(\mathrm{~d}, J=$ $7.5 \mathrm{~Hz}, 3 \mathrm{H}), 0.86$ (s, 9H), 0.06 (s, 3H), 0.05 (s, 3H); ${ }^{13} \mathrm{C} \mathrm{NMR}\left(125 \mathrm{MHz}, \mathrm{CDCl}_{3}\right) \delta$ 174.2, 86.2, 68.0, 68.0, 51.3, 35.0, 33.9, 29.9, 25.8 (x 3), 25.6, 17.9 (x 2), -3.9, -4.9; HRMS (FAB) calcd for $\mathrm{C}_{16} \mathrm{H}_{33} \mathrm{O}_{4} \mathrm{Si}$ $\left[(\mathrm{M}+\mathrm{H})^{+}\right]$317.2148, found 317.2150.

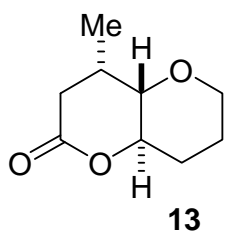

(2) Sakata, H.; Aoki, Y.; Kuwajima, I. Tetrahedron Lett. 1990, 31, 1161-1164. 
Lactone 13. To a solution of ester $12(2.3 \mathrm{mg}, 7.30 \mu \mathrm{mol})$ in methanol $(0.07 \mathrm{~mL})$ was added $1 \%$ $\mathrm{HCl}$ in methanol $(0.35 \mathrm{~mL})$. The resultant mixture was stirred at room temperature for $2 \mathrm{~h}$ and quenched with saturated aqueous $\mathrm{NaHCO}_{3}$. The mixture was diluted with ethyl acetate and washed with brine. The organic layer was dried over $\mathrm{Na}_{2} \mathrm{SO}_{4}$, filtered and concentrated under reduced pressure. The crude alcohol was used directly in the subsequent reaction without purification.

To a solution the above alcohol in benzene $(0.54 \mathrm{~mL})$ was added PPTS $(0.9 \mathrm{mg}, 3.7 \mu \mathrm{mol})$. The resultant mixture was stirred at $80{ }^{\circ} \mathrm{C}$ for $10 \mathrm{~h}$. Toluene $(1.0 \mathrm{~mL})$ was added and the mixture was stirred at $110{ }^{\circ} \mathrm{C}$ for further $5 \mathrm{~h}$. The reaction mixture was cooled to room temperature and quenched with saturated aqueous $\mathrm{NaHCO}_{3}$. The mixture was diluted with ethy acetate and washed with brine. The organic layer was dried over $\mathrm{Na}_{2} \mathrm{SO}_{4}$, filtered and concentrated under reduced pressure. Purification by column chromatography on silica gel (30\% ethyl acetate/hexanes) afforded lactone $\mathbf{1 3}$ (1.0 mg, 79\% for the two steps) as a colorless oil: $[\alpha]^{20}{ }_{\mathrm{D}}+105.6\left(c 0.07, \mathrm{CHCl}_{3}\right) ;{ }^{1} \mathrm{H} \mathrm{NMR}(500 \mathrm{MHz}$, $\left.\mathrm{CDCl}_{3}\right) \delta 4.12(\mathrm{ddd}, J=10.5,10.5,5.0 \mathrm{~Hz}, 1 \mathrm{H}), 3.98-3.95(\mathrm{~m}, 1 \mathrm{H}), 3.47$ (ddd, $J=11.5,11.5,3.5 \mathrm{~Hz}$, $1 \mathrm{H}), 3.36(\mathrm{dd}, J=9.0,5.0 \mathrm{~Hz}, 1 \mathrm{H}), 2.75(\mathrm{dd}, J=18.0,7.5 \mathrm{~Hz}, 1 \mathrm{H}), 2.45(\mathrm{dd}, J=17.5,3.5 \mathrm{~Hz}, 1 \mathrm{H})$, $2.34(\mathrm{ddd}, J=13.0,6.5,4.0 \mathrm{~Hz}, 1 \mathrm{H}), 2.25(\mathrm{~m}, 1 \mathrm{H}), 1.73-1.54(\mathrm{~m}, 3 \mathrm{H}), 1.07(\mathrm{~d}, J=7.5 \mathrm{~Hz}, 3 \mathrm{H}) ;{ }^{13} \mathrm{C}$ NMR (125 MHz, $\left.\mathrm{CDCl}_{3}\right) \delta 197.1,72.9,68.4,37.5,31.2,30.1,29.0,25.1,14.7$; HRMS (EI) calcd for $\mathrm{C}_{9} \mathrm{H}_{14} \mathrm{O}_{3}\left(\mathrm{M}^{+}\right)$170.0943, found 170.0951 .

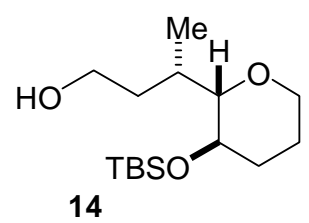

Alcohol 14. To a solution of ester $12(0.36 \mathrm{~g}, 1.14 \mathrm{mmol})$ in $\mathrm{CH}_{2} \mathrm{Cl}_{2}(11 \mathrm{~mL})$ at $-78^{\circ} \mathrm{C}$ was added DIBALH $(0.95 \mathrm{M}$ in hexane, $3.0 \mathrm{ml}, 2.84 \mathrm{mmol})$. The resultant mixture was stirred at $-78{ }^{\circ} \mathrm{C}$ for $2 \mathrm{~h}$ and quenched with saturated aqueous potassium sodium tartrate. The mixture was vigorously stirred until the layers became clear. The organic layer was separated, washed with brine, dried over $\mathrm{Na}_{2} \mathrm{SO}_{4}$, filtered and concentrated under reduced pressure. Purification by column chromatography on silica gel (40\% ethyl acetate/hexanes) afforded alcohol $14(0.34 \mathrm{~g}, 99 \%)$ as a colorless oil: $[\alpha]^{21}-25.1(c$ 1.34, $\mathrm{CHCl}_{3}$ ); ${ }^{1} \mathrm{H}$ NMR (500 MHz, $\left.\mathrm{C}_{6} \mathrm{D}_{6}\right) \delta 3.70-3.55(\mathrm{~m}, 5 \mathrm{H}), 3.00-2.95(\mathrm{~m}, 2 \mathrm{H}), 2.34-2.31(\mathrm{~m}, 1 \mathrm{H})$, 2.02 (br, 1H), 1.84-1.82 (m, 1H), 1.76 (ddd, $J=14.0,14.0,7.5 \mathrm{~Hz}, 1 \mathrm{H}), 1.70-1.64(\mathrm{~m}, 1 \mathrm{H})$, 1.41-1.32 (m, 1H), 1.29-1.18 (m, 1H), 1.10 (d, J = 7.5 Hz, 3H), 0.95 (s, 9H), 0.08 (s, 3H), 0.04 (s, $3 \mathrm{H}) ;{ }^{13} \mathrm{C}$ NMR $\left(125 \mathrm{MHz}, \mathrm{C}_{6} \mathrm{D}_{6}\right.$ ) $\delta$ 87.2, 68.1, 68.1, 59.9, 34.3, 33.0, 30.0, 26.0 (x 3), 25.8, 18.1, 17.2, -3.6, -4.6; HRMS (FAB) calcd for $\mathrm{C}_{15} \mathrm{H}_{33} \mathrm{O}_{3} \mathrm{Si}\left[(\mathrm{M}+\mathrm{H})^{+}\right]$289.2199, found 289.2204. 


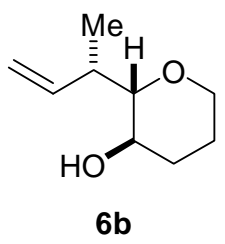

Alcohol 6b. To a solution of alcohol $14(0.89 \mathrm{~g}, 3.08 \mathrm{mmol})$ in THF (15 mL) were added $o$-nitrophenyl selenocyanate $(1.05 \mathrm{ml}, 4.62 \mathrm{mmol})$ and tri- $n$-butylphosphine $(1.53 \mathrm{ml}, 6.16 \mathrm{mmol})$. The resultant mixture was stirred at room temperature for $30 \mathrm{~min}$ and concentrated under reduced pressure. The residue was filtered through a plug of silica gel (10\% ethyl acetate/hexanes) to give $o$-nitrophenyl selenide, which was used directly in the subsequent reaction.

To a solution the above selenide in $\mathrm{CH}_{2} \mathrm{Cl}_{2}(31 \mathrm{~mL})$ at $0{ }^{\circ} \mathrm{C}$ was added $m \mathrm{CPBA}(77 \%, 1.39 \mathrm{~g}$, $6.16 \mathrm{mmol}$ ). The resultant mixture was stirred at $0{ }^{\circ} \mathrm{C}$ for $30 \mathrm{~min}$ and quenched with triethylamine. The mixture was stirred at $35{ }^{\circ} \mathrm{C}$ for further $12 \mathrm{~h}$ and concentrated under reduced pressure. Purification by column chromatography on silica gel (10\% ethyl acetate/hexanes) afforded olefin $(0.77 \mathrm{~g}, 91 \%$ for the two steps), which was used directly in the subsequent reaction.

To a solution of the above olefin $(0.77 \mathrm{~g}, 2.81 \mathrm{mmol})$ in THF $(28 \mathrm{~mL})$ at $0{ }^{\circ} \mathrm{C}$ was added tetra- $n$-butylammonium fluoride $(1.0 \mathrm{M}$ in THF, $5.6 \mathrm{~mL}, 5.62 \mathrm{mmol})$. The resultant mixture was stirred at room temperature for $15 \mathrm{~h}$ and quenched with saturated aqueous $\mathrm{NH}_{4} \mathrm{Cl}$. The organic layer was separated, washed with brine, dried over $\mathrm{Na}_{2} \mathrm{SO}_{4}$, filtered and concentrated under reduced pressure. Purification by column chromatography on silica gel (40\% ethyl acetate/hexanes) afforded alcohol 6b (0.42 g, 94\%) as a yellow oil: $[\alpha]^{21} \mathrm{D}-18.9$ (c 3.83, $\left.\mathrm{CHCl}_{3}\right) ;{ }^{1} \mathrm{H} \mathrm{NMR}\left(500 \mathrm{MHz}, \mathrm{CDCl}_{3}\right) \delta$ 5.88 (ddd, $J=17.0,10.0,8.0 \mathrm{~Hz}, 1 \mathrm{H}), 5.09-5.03(\mathrm{~m}, 2 \mathrm{H}), 3.91-3.88(\mathrm{~m}, 1 \mathrm{H}), 3.47-3.42(\mathrm{~m}, 1 \mathrm{H})$, $3.31-3.23(\mathrm{~m}, 1 \mathrm{H}), 2.95(\mathrm{dd}, J=9.0,2.5 \mathrm{~Hz}, 1 \mathrm{H}), 2.66(\mathrm{ddd}, J=14.5,7.5,6.0 \mathrm{~Hz}, 1 \mathrm{H}), 2.05(\mathrm{~m}, 1 \mathrm{H})$, $1.64-1.56(\mathrm{~m}, 2 \mathrm{H}), 1.45(\mathrm{~d}, J=4.0 \mathrm{~Hz}, 1 \mathrm{H}), 1.42-1.34(\mathrm{~m}, 1 \mathrm{H}), 1.10(\mathrm{~d}, J=7.0 \mathrm{~Hz}, 3 \mathrm{H}) ;{ }^{13} \mathrm{C} \mathrm{NMR}$ $\left(125 \mathrm{MHz}, \mathrm{CDCl}_{3}\right) \delta 139.9,115.1,85.5,67.9,67.8,38.6,32.9,25.6,16.9$; HRMS (FAB) calcd for $\mathrm{C}_{9} \mathrm{H}_{17} \mathrm{O}_{2}\left[(\mathrm{M}+\mathrm{H})^{+}\right]$157.1229, found 157.1231.

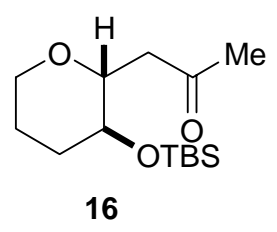

Methyl Ketone 16. To a solution of olefin $\mathbf{1 5}^{3}$ (3.12 g, $\left.12.9 \mathrm{mmol}\right)$ in $\mathrm{THF}(43 \mathrm{~mL})$ at $0{ }^{\circ} \mathrm{C}$ was added 9-BBN (0.5 $\mathrm{M}$ in THF, $103 \mathrm{ml}, 51.6 \mathrm{mmol})$. The resultant mixture was stirred at room temperature for $20 \mathrm{~h}$. The solution was cooled to $0{ }^{\circ} \mathrm{C}$ and treated with $10 \%$ aqueous $\mathrm{NaOH}(72 \mathrm{~mL})$ followed by $30 \% \mathrm{H}_{2} \mathrm{O}_{2}(58 \mathrm{~mL})$. The resultant mixture was stirred at room temperature for $9 \mathrm{~h}$ and diluted with ethyl acetate. The organic layer was washed with saturated aqueous $\mathrm{Na}_{2} \mathrm{SO}_{3}$ and brine,

(3) Nicolaou, K. C.; Hwang, C. K.; Marron, B. E.; DeFrees, S. A.; Couladouros, E. A.; Abe, Y.; Carroll, P. J.; Snyder, J. P. J. Am. Chem. Soc. 1990, 112, 3040-3054. 
dried over $\mathrm{Na}_{2} \mathrm{SO}_{4}$, filtered and concentrated under reduced pressure. Purification by column chromatography on silica gel (30\% ethyl acetate/hexanes) afforded alcohol (3.16 g), which was used directly in the subsequent reaction.

To a solution of the above alcohol in $\mathrm{CH}_{2} \mathrm{Cl}_{2} / \mathrm{DMSO}(1: 1$, v/v, $48 \mathrm{~mL})$ at $0{ }^{\circ} \mathrm{C}$ were added triethylamine $(8.0 \mathrm{~mL}, 60.0 \mathrm{mmol})$ and $\mathrm{SO}_{3}$.pyridine $(7.63 \mathrm{~g}, 48.0 \mathrm{mmol})$. The resultant mixture was stirred at room temperature for $2.5 \mathrm{~h}$ and quenched with water. The solution was diluted with ethyl acetate, washed with $1 \mathrm{M}$ aqueous $\mathrm{HCl}$, saturated aqueous $\mathrm{NaHCO}_{3}$ and brine. The organic layer was dried over $\mathrm{Na}_{2} \mathrm{SO}_{4}$, filtered and concentrated under reduced pressure. Purification by column chromatography on silica gel (30\% ethyl acetate/hexanes) afforded aldehyde, which was used directly in the subsequent reaction.

To a solution of the above aldehyde in THF $(40 \mathrm{~mL})$ at $0{ }^{\circ} \mathrm{C}$ was added methylmagnesium bromide (3.0 M in ether, $4.0 \mathrm{~mL}, 47.6 \mathrm{mmol})$. The resultant mixture was stirred at room temperature for $3 \mathrm{~h}$ and quenched with saturated aqueous $\mathrm{NH}_{4} \mathrm{Cl}$. The mixture was diluted with ethyl acetate, washed with water and brine, dried over $\mathrm{Na}_{2} \mathrm{SO}_{4}$, filtered and concentrated under reduced pressure. Purification by column chromatography on silica gel (40\% ethyl acetate/hexanes) afforded alcohol $(3.04 \mathrm{~g})$, which was used directly in the subsequent reaction.

To a suspension of the above alcohol and $4 \AA$ molecular sieves in $\mathrm{CH}_{2} \mathrm{Cl}_{2}(36 \mathrm{~mL})$ were added $N$-methylmorpholine $N$-oxide $(2.50 \mathrm{~g}, 21.9 \mathrm{mmol})$ and tetra- $n$-propylammonium perruthenate $(0.31 \mathrm{~g}$, $0.87 \mathrm{mmol}$ ). The resultant mixture was stirred at $0{ }^{\circ} \mathrm{C}$ for $2 \mathrm{~h}$ and then at room temperature for $1 \mathrm{~h}$. The mixture was concentrated under reduced pressure and the residue was purified by column chromatography on silica gel (20\% ethyl acetate/hexanes) to afford methyl ketone $\mathbf{1 6}(2.89 \mathrm{~g}, 82 \%$ for the four steps) as a colorless oil: $[\alpha]^{21}+72.1\left(c 0.18, \mathrm{CHCl}_{3}\right) ;{ }^{1} \mathrm{H}$ NMR $\left(500 \mathrm{MHz}, \mathrm{CDCl}_{3}\right) \delta$ $3.82-3.79(\mathrm{~m}, 1 \mathrm{H}), 3.51(\mathrm{ddd}, J=9.5,9.5,3.0 \mathrm{~Hz}, 1 \mathrm{H}), 3.35-3.33(\mathrm{~m}, 2 \mathrm{H}), 2.79(\mathrm{dd}, J=15.5,2.5 \mathrm{~Hz}$, $1 \mathrm{H}), 2.42(\mathrm{dd}, J=15.5,9.5 \mathrm{~Hz}, 1 \mathrm{H}), 2.16(\mathrm{~s}, 3 \mathrm{H}), 2.00-1.97(\mathrm{~m}, 1 \mathrm{H}), 1.66-1.54(\mathrm{~m}, 2 \mathrm{H}), 1.48-1.39$ $(\mathrm{m}, 1 \mathrm{H}), 0.84(\mathrm{~s}, 9 \mathrm{H}), 0.03(\mathrm{~s}, 3 \mathrm{H}), 0.03(\mathrm{~s}, 3 \mathrm{H}) ;{ }^{13} \mathrm{C} \mathrm{NMR}\left(125 \mathrm{MHz}, \mathrm{CDCl}_{3}\right) \delta 207.9,79.4,71.0$, 67.8, 46.9, 33.4, 30.6, 25.7 (x 3), 25.5, 17.9, -4.0, -4.8; HRMS (FAB) calcd for $\mathrm{C}_{14} \mathrm{H}_{29} \mathrm{O}_{3} \mathrm{Si}\left[(\mathrm{M}+\mathrm{H})^{+}\right]$ 273.1886 , found 273.1886 .

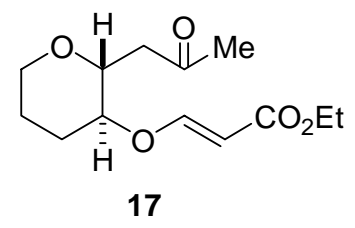

$\beta$-Alkoxyacrylate 17. To a solution of methyl ketone $\mathbf{1 6}(2.89 \mathrm{~g}, 10.6 \mathrm{mmol})$ in THF (54 mL) at $0{ }^{\circ} \mathrm{C}$ was added tetra- $n$-butylammonium fluoride $(1.0 \mathrm{M}$ in THF, $21.2 \mathrm{ml}, 21.2 \mathrm{mmol})$. The resultant mixture was stirred at room temperature for $14 \mathrm{~h}$. The mixture was concentrated under reduced pressure and purified by column chromatography on silica gel (70\% ethyl acetate/hexanes) to afford alcohol $(1.58 \mathrm{~g}, 91 \%)$, which was used directly in the subsequent reaction. 
To a solution of the above alcohol $(1.58 \mathrm{~g}, 9.69 \mathrm{mmol})$ in $\mathrm{CH}_{2} \mathrm{Cl}_{2}(48 \mathrm{~mL})$ at $0{ }^{\circ} \mathrm{C}$ were added $N$-methylmorpholine $(1.48 \mathrm{ml}, 14.5 \mathrm{mmol})$ and ethyl propiolate $(3.19 \mathrm{ml}, 29.1 \mathrm{mmol})$. The resultant mixture was stirred at room temperature for $14 \mathrm{~h}$. The mixture was concentrated under reduced pressure and purified by column chromatography on silica gel (30\% ethyl acetate/hexanes) to afford $\beta$-alkoxyacrylate $17(2.22 \mathrm{~g}, 89 \%)$ as a pale yellow oil: $[\alpha]^{21}{ }_{\mathrm{D}}+15.8\left(c 1.87, \mathrm{CHCl}_{3}\right) ;{ }^{1} \mathrm{H} \mathrm{NMR}(500$ $\left.\mathrm{MHz} \mathrm{CDCl}_{3}\right) \delta 7.43(\mathrm{~d}, J=12.0 \mathrm{~Hz}, 1 \mathrm{H}), 5.24(\mathrm{~d}, J=12.0 \mathrm{~Hz}, 1 \mathrm{H}), 4.12(\mathrm{dd}, J=11.0,4.0 \mathrm{~Hz}, 2 \mathrm{H})$, $3.86-3.83$ (m, 1H), 3.72 (ddd, $J=9.5,9.5,3.5 \mathrm{~Hz}, 1 \mathrm{H}), 3.63$ (ddd, $J=10.5,10.5,4.5 \mathrm{~Hz}, 1 \mathrm{H}), 3.36$ $(\mathrm{ddd}, J=11.5,11.5,3.5 \mathrm{~Hz}, 1 \mathrm{H}), 2.68(\mathrm{dd}, J=16.0,3.0 \mathrm{~Hz}, 1 \mathrm{H}), 2.52(\mathrm{dd}, J=15.5,9.0 \mathrm{~Hz}, 1 \mathrm{H}), 2.21$ (m, 1H), 2.15 (s, 3H), 1.72-1.62 (m, 2H), 1.50 (dddd, $J=12.5,12.5,12.5,5.5 \mathrm{~Hz}, 1 \mathrm{H}), 1.23(\mathrm{t}, J=7.5$ $\mathrm{Hz}, 3 \mathrm{H}) ;{ }^{13} \mathrm{C} \mathrm{NMR}\left(125 \mathrm{MHz}, \mathrm{CDCl}_{3}\right) \quad \delta 206.3,167.6,160.8,98.4,79.9,76.1,67.6,59.8,45.9,31.0$, 29.4, 25.0, 14.3; HRMS (FAB) calcd for $\mathrm{C}_{13} \mathrm{H}_{21} \mathrm{O}_{5}\left[(\mathrm{M}+\mathrm{H})^{+}\right] 257.1389$, found 257.1394.

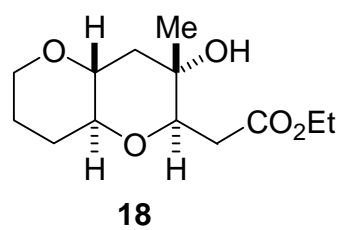

Bicyclic Ether 18. To a solution of $\beta$-alkoxyacrylate $17(0.15 \mathrm{~g}, 0.63 \mathrm{mmol})$ in THF $(6.3 \mathrm{~mL})$ at $0{ }^{\circ} \mathrm{C}$ were added methanol $(60 \mu \mathrm{L})$ and $\mathrm{SmI}_{2}(0.1 \mathrm{M}$ in THF, $18.9 \mathrm{~mL}, 1.89 \mathrm{mmol})$. The resultant mixture was stirred at $0{ }^{\circ} \mathrm{C}$ for 15 min and quenched with $50 \%$ aqueous $\mathrm{Na}_{2} \mathrm{~S}_{2} \mathrm{O}_{3}$ and saturated aqueous $\mathrm{NaHCO}_{3}$. The mixture was diluted with ethyl acetate, washed with brine, dried over $\mathrm{Na}_{2} \mathrm{SO}_{4}$, filtered and concentrated under reduced pressure. Purification by column chromatography on silica gel (30\% ethyl acetate/hexanes) afforded bicyclic ether $18(0.15 \mathrm{~g}, 99 \%)$ as a colorless solid: $[\alpha]^{21}{ }_{\mathrm{D}}$ $+28.9\left(c^{c} 2.26, \mathrm{CHCl}_{3}\right)$; ${ }^{1} \mathrm{H}$ NMR (500 MHz, $\left.\mathrm{CDCl}_{3}\right) \delta 4.19-4.09(\mathrm{~m}, 2 \mathrm{H}), 3.89-3.84(\mathrm{~m}, 1 \mathrm{H}), 3.69$ (dd, $J=9.5,4.0 \mathrm{~Hz}, 1 \mathrm{H}), 3.34$ (ddd, $J=11.5,11.5,7.0 \mathrm{~Hz}, 1 \mathrm{H}), 3.05(\mathrm{ddd}, J=9.5,9.5,4.5 \mathrm{~Hz}, 1 \mathrm{H}), 2.96$ (ddd, $J=12.0,12.0,4.5 \mathrm{~Hz}, 1 \mathrm{H}), 2.68(\mathrm{dd}, J=15.0,3.0 \mathrm{~Hz}, 1 \mathrm{H}), 2.37(\mathrm{dd}, J=15.5,9.0 \mathrm{~Hz}, 1 \mathrm{H}), 2.12$ $(\mathrm{dd}, J=12.0,4.5 \mathrm{~Hz}, 1 \mathrm{H}), 2.02(\mathrm{ddd}, J=8.0,8.0,3.5 \mathrm{~Hz}, 1 \mathrm{H}), 1.73-1.66(\mathrm{~m}, 3 \mathrm{H}), 1.60-1.51(\mathrm{~m}, 1 \mathrm{H})$, $1.44-1.36(\mathrm{~m}, 1 \mathrm{H}), 1.24(\mathrm{t}, J=7.0 \mathrm{~Hz}, 3 \mathrm{H}), 1.21(\mathrm{~s}, 3 \mathrm{H}) ;{ }^{13} \mathrm{C} \mathrm{NMR}\left(125 \mathrm{MHz}, \mathrm{CDCl}_{3}\right) \delta 172.2,81.0$, 79.0, 76.7, 70.8, 67.9, 60.7, 46.0, 34.9, 29.2, 25.5, 21.4, 14.2; HRMS (FAB) calcd for $\mathrm{C}_{13} \mathrm{H}_{23} \mathrm{O}_{5}$ $\left[(\mathrm{M}+\mathrm{H})^{+}\right] 259.1545$, found 259.1547 .

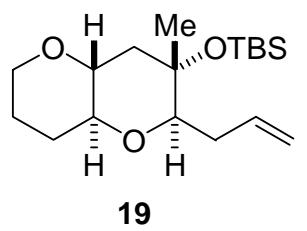

Olefin 19 To a solution of bicyclic ether $18(0.63 \mathrm{~g}, 2.31 \mathrm{mmol})$ in $\mathrm{CH}_{2} \mathrm{Cl}_{2}(12 \mathrm{~mL})$ at $0{ }^{\circ} \mathrm{C}$ were added 2,6-lutidine $(0.72 \mathrm{~mL}, 6.23 \mathrm{mmol})$ and TBSOTf $(0.78 \mathrm{~g}, 4.62 \mathrm{mmol})$. The resultant mixture 
was stirred at $0{ }^{\circ} \mathrm{C}$ for $1 \mathrm{~h}$ and at room temperature for $12 \mathrm{~h}$. The reaction mixture was quenched with saturated aqueous $\mathrm{NaHCO}_{3}$, diluted with ethyl acetate and washed with brine. The organic layer was dried over $\mathrm{Na}_{2} \mathrm{SO}_{4}$, filtered and concentrated under reduced pressure. The residue was filtered through a plug of silica gel (20\% ethyl acetate/hexanes) to give TBS ether, which was used directly in the subsequent reaction.

To a solution of the above TBS ether in $\mathrm{CH}_{2} \mathrm{Cl}_{2}(20 \mathrm{~mL})$ at $-78{ }^{\circ} \mathrm{C}$ was added DIBALH $(0.95 \mathrm{M}$ in hexane, $2.9 \mathrm{ml}, 2.77 \mathrm{mmol})$. The resultant mixture was stirred at $-78{ }^{\circ} \mathrm{C}$ for $1.5 \mathrm{~h}$ and quenched with saturated aqueous potassium sodium tartrate. The mixture was diluted with ethyl acetate and vigorously stirred until the layers became clear. The organic layer was separated, washed with brine, dried over $\mathrm{Na}_{2} \mathrm{SO}_{4}$, filtered and concentrated under reduced pressure. The obtained crude aldehyde was used directly in the subsequent reaction without purification.

To a solution of $\mathrm{Ph}_{3} \mathrm{PCH}_{3} \mathrm{Br}(2.5 \mathrm{~g}, 6.93 \mathrm{mmol})$ in $\mathrm{CH}_{2} \mathrm{Cl}_{2}(5 \mathrm{~mL})$ at $0{ }^{\circ} \mathrm{C}$ was added NaHMDS (1.0 M in THF, $4.62 \mathrm{~mL}, 4.62 \mathrm{mmol}$ ). The resultant ylide solution was stirred at $0{ }^{\circ} \mathrm{C}$ for $30 \mathrm{~min}$. A solution of the above crude aldehyde in THF $(5.0 \mathrm{~mL})$ was added and the mixture was stirred at room temperature for $9 \mathrm{~h}$. The reaction mixture was quenched with saturated aqueous $\mathrm{NH}_{4} \mathrm{Cl}$, diluted with ether and washed with brine. The organic layer was separated and dried over $\mathrm{Na}_{2} \mathrm{SO}_{4}$, filtered and concentrated under reduced pressure. Purification by column chromatography on silica gel (20\% ethyl acetate/hexanes) afforded olefin $19(0.61 \mathrm{~g}, 81 \%$ for the three steps $)$ as a colorless oil: $[\alpha]^{21}$ +48.4 (c 1.11, $\left.\mathrm{CHCl}_{3}\right) ;{ }^{1} \mathrm{H} \mathrm{NMR}\left(500 \mathrm{MHz}, \mathrm{CDCl}_{3}\right) \delta 5.94-5.85(\mathrm{~m}, 1 \mathrm{H}), 5.06(\mathrm{~d}, J=17.0 \mathrm{~Hz}, 1 \mathrm{H})$, $5.00(\mathrm{~d}, J=10.5 \mathrm{~Hz}, 1 \mathrm{H}), 3.88-3.86(\mathrm{~m}, 1 \mathrm{H}), 3.37-3.31(\mathrm{~m}, 1 \mathrm{H}), 3.15-3.13(\mathrm{~m}, 1 \mathrm{H}), 3.00-2.91$ (m, 2H), $2.43(\mathrm{dd}, J=15.0,7.5 \mathrm{~Hz}, 1 \mathrm{H}), 2.10(\mathrm{dd}, \mathrm{J}=11.5,4.5 \mathrm{~Hz}, 1 \mathrm{H}), 2.05-1.96(\mathrm{~m}, 2 \mathrm{H}), 1.71-1.60(\mathrm{~m}$, $3 \mathrm{H}), 1.45-1.37(\mathrm{~m}, 1 \mathrm{H}), 1.20(\mathrm{~s}, 3 \mathrm{H}), 0.83(\mathrm{~s}, 9 \mathrm{H}), 0.07(\mathrm{~s}, 6 \mathrm{H}),{ }^{13} \mathrm{C} \mathrm{NMR}\left(125 \mathrm{MHz}, \mathrm{CDCl}_{3}\right) \delta 136.8$, 115,7, 85.2, 78.8, 76.8, 73.5, 67.9, 46.1, 33.0, 29.3, 25.7, 25.6 (x 3), 22.2, 18.0, -2.0, -2.1; HRMS (FAB) calcd for $\mathrm{C}_{18} \mathrm{H}_{34} \mathrm{O}_{3} \mathrm{SiNa}\left[(\mathrm{M}+\mathrm{Na})^{+}\right] 349.2175$ found 349.2177 .

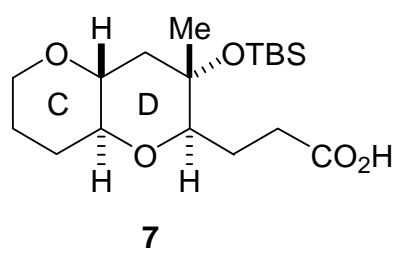

Carboxylic Acid 7. To a solution of olefin 19 (1.82 g, $5.58 \mathrm{mmol})$ in THF $(84 \mathrm{~mL})$ at $0{ }^{\circ} \mathrm{C}$ was added 9-BBN $(0.5 \mathrm{M}$ in THF, $44 \mathrm{ml}, 22.0 \mathrm{mmol})$. The resultant mixture was stirred at room temperature for $4 \mathrm{~h}$. The mixture was cooled to $0{ }^{\circ} \mathrm{C}$, treated with $10 \%$ aqueous $\mathrm{NaOH}(33 \mathrm{~mL})$ followed by $30 \% \mathrm{H}_{2} \mathrm{O}_{2}(26 \mathrm{~mL})$ and stirred at room temperature for $12 \mathrm{~h}$. The reaction mixture was diluted with ethyl acetate, washed with saturated aqueous $\mathrm{Na}_{2} \mathrm{SO}_{3}$ and brine. The organic layer was dried over $\mathrm{Na}_{2} \mathrm{SO}_{4}$, filtered and concentrated under reduced pressure. Purification by column chromatography on silica gel (30\% ethyl acetate/hexanes) afforded alcohol (1.74 g, 91\%), which was 
used directly in the subsequent reaction.

To a solution of the above alcohol in $\mathrm{CH}_{2} \mathrm{Cl}_{2} / \mathrm{DMSO}(1: 1$, v/v, $50 \mathrm{~mL})$ at $0{ }^{\circ} \mathrm{C}$ were added triethylamine $(3.48 \mathrm{~mL}, 25.0 \mathrm{mmol})$ and $\mathrm{SO}_{3}$.pyridine $(3.18 \mathrm{~g}, 20.0 \mathrm{mmol})$. The resultant mixture was stirred at room temperature for $4 \mathrm{~h}$. The reaction mixture was quenched with water, diluted with diethyl ether, washed with water and brine. The organic layer was dried over $\mathrm{Na}_{2} \mathrm{SO}_{4}$, filtered and concentrated under reduced pressure to give crude aldehyde, which was used directly in the subsequent reaction without purification.

To a solution of the above aldehyde in $t$-BuOH/water $(4: 1, \mathrm{v} / \mathrm{v}, 50 \mathrm{~mL})$ at $0{ }^{\circ} \mathrm{C}$ were added 2-methyl-2-butene (2.43 mL, $22.9 \mathrm{mmol}), \mathrm{KH}_{2} \mathrm{PO}_{4}(0.69 \mathrm{~g}, 5.08 \mathrm{mmol})$ and $\mathrm{NaClO}_{2}(1.61 \mathrm{~g}, 17.8$ $\mathrm{mmol}$ ). The resultant mixture was stirred at room temperature for $2 \mathrm{~h}$. The reaction mixture was diluted with $\mathrm{CHCl}_{3}$ and washed with $1 \mathrm{M}$ aqueous $\mathrm{HCl}$. The organic layer was dried over $\mathrm{Na}_{2} \mathrm{SO}_{4}$, filtered and concentrated under reduced pressure. Purification by column chromatography on silica gel (10\% methanol/ $\left.\mathrm{CHCl}_{3}\right)$ afforded carboxylic acid 7 (1.75 g, 96\% for the two steps) as a colorless oil: ${ }^{1} \mathrm{H}$ NMR $\left(500 \mathrm{MHz}, \mathrm{CDCl}_{3}\right) \delta 3.88-3.86(\mathrm{~m}, 1 \mathrm{H}), 3.34(\mathrm{ddd}, J=15.5,8.5,6.0 \mathrm{~Hz}, 1 \mathrm{H}), 3.08(\mathrm{dd}$, $J=10.5,1.5 \mathrm{~Hz}, 1 \mathrm{H}), 2.99-2.90(\mathrm{~m}, 2 \mathrm{H}), 2.53$ (ddd, $J=16.5,8.5,6.5 \mathrm{~Hz}, 1 \mathrm{H}), 2.40$ (ddd, $J=15.5,7.5$, $7.5 \mathrm{~Hz}, 1 \mathrm{H}), 2.12-1.99(\mathrm{~m}, 3 \mathrm{H}), 1.73-1.16(\mathrm{~m}, 9 \mathrm{H}), 0.82(\mathrm{~s}, 9 \mathrm{H}), 0.07$ (s, 6H); ${ }^{13} \mathrm{C} \mathrm{NMR}(125 \mathrm{MHz}$, $\left.\mathrm{CDCl}_{3}\right) \delta 199.1,84.5,78.8,76.7,73.4,67.9,46.1,31.6,29.2,25.7$ (x 3), 25.5, 23.6, 22.1, 17.9, -2.02, -2.07; HRMS (FAB) calcd for $\mathrm{C}_{18} \mathrm{H}_{35} \mathrm{O}_{5} \mathrm{Si}\left[(\mathrm{M}+\mathrm{H})^{+}\right]$359.2254, found 359.2255.

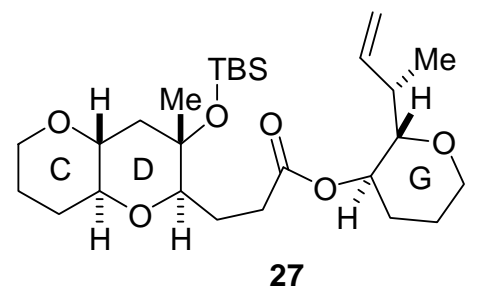

Ester 27. To a solution of carboxylic acid $7(0.71 \mathrm{~g}, 1.98 \mathrm{~mol})$ in $\mathrm{THF}(20 \mathrm{~mL})$ at $0{ }^{\circ} \mathrm{C}$ were added triethylamine $(0.41 \mathrm{~mL}, 2.97 \mathrm{mmol})$ and 2,4,6-trichlorobenzoyl chloride $(0.40 \mathrm{~mL}, 2.57 \mathrm{mmol})$. The resultant mixture was stirred at $40{ }^{\circ} \mathrm{C}$ for $1.5 \mathrm{~h}$ and concentrated under reduced pressure. The mixture was dissolved in toluene $(20 \mathrm{~mL})$ and treated with alcohol $6 \mathbf{b}(0.31 \mathrm{~g}, 1.98 \mathrm{mmol})$ and DMAP $(0.48 \mathrm{~g}, 3.96 \mathrm{mmol})$. The mixture was stirred at $40{ }^{\circ} \mathrm{C}$ for $2.5 \mathrm{~h}$ and quenched with saturated aqueous $\mathrm{NH}_{4} \mathrm{Cl}$. The reaction mixture was diluted with ethyl acetate, washed with brine and saturated aqueous $\mathrm{NaHCO}_{3}$, dried over $\mathrm{Na}_{2} \mathrm{SO}_{4}$, filtered and concentrated under reduced pressure. Purification by column chromatography on silica gel (20\% ethyl acetate/hexanes) afforded ester $27(0.90 \mathrm{~g}, 92 \%)$ as a pale yellow oil: $[\alpha]^{21}{ }_{\mathrm{D}}+21.7\left(c 1.47, \mathrm{CHCl}_{3}\right) ;{ }^{1} \mathrm{H} \mathrm{NMR}\left(500 \mathrm{MHz}, \mathrm{CDCl}_{3}\right) \delta 5.78$ (ddd, $J=18.5$, $17.5,10.5 \mathrm{~Hz}, 1 \mathrm{H}), 4.99$ (dd, $J=11.0,1.5 \mathrm{~Hz}, 1 \mathrm{H}), 4.90(\mathrm{~d}, J=17.5 \mathrm{~Hz}, 1 \mathrm{H}), 4.60$ (ddd, $J=12.5,4.5$ $\mathrm{Hz}, 1 \mathrm{H}), 3.93-3.86(\mathrm{~m}, 2 \mathrm{H}), 3.38-3.27(\mathrm{~m}, 2 \mathrm{H}), 3.17(\mathrm{dd}, J=9.5,2.5 \mathrm{~Hz}, 1 \mathrm{H}), 3.05(\mathrm{dd}, J=10.5,1.5$ $\mathrm{Hz}, 1 \mathrm{H}), 2.97-2.90$ (m, 2H), 2.50 (ddd, $J=15.5,10.0,5.5 \mathrm{~Hz}, 1 \mathrm{H}), 2.41$ (ddd, $J=13.5,7.0,7.0 \mathrm{~Hz}$, $1 \mathrm{H}), 2.27$ (ddd, $J=15.5,10.0,6.5 \mathrm{~Hz}, 1 \mathrm{H}), 2.18-2.15(\mathrm{~m}, 1 \mathrm{H}), 2.11(\mathrm{dd}, J=11.5,4.0 \mathrm{~Hz}, 1 \mathrm{H})$, 
2.04-1.98 (m, 2H), 1.71-1.50 (m, 6H), 1.43-1.33 (m, 2H), $1.20(\mathrm{~s}, 3 \mathrm{H}) 1.08$ (d, J = 7.0 Hz, 3H), 0.83 (s, 9H), 0.074 (s, 3H), 0.072 (s, 3H); ${ }^{13} \mathrm{C}$ NMR $\left(125 \mathrm{MHz}, \mathrm{CDCl}_{3}\right) \delta 172.4,138.9,115.4,84.5,83.1$, 78.9, 76.8, 73.4, 69.5, 68.0, 67.9, 46.2, 38.5, 32.1, 29,5, 29.3, 25.7 (x 3), 25,6, 25,1, 24.0, 22.2, 18.0, 17.0, -2.00, -2.08; HRMS (FAB) calcd for $\mathrm{C}_{27} \mathrm{H}_{49} \mathrm{O}_{6} \mathrm{Si}\left[(\mathrm{M}+\mathrm{H})^{+}\right] 497.3298$, found 497.3300.

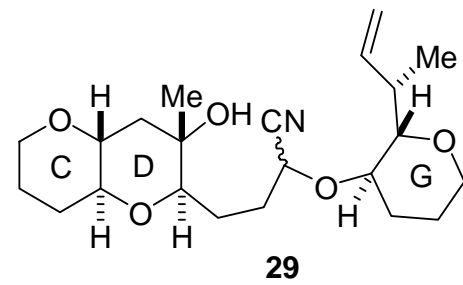

Alcohol 29. To a solution of ester $27(0.29 \mathrm{~g}, 0.61 \mathrm{~mol})$ in $\mathrm{CH}_{2} \mathrm{Cl}_{2}(12 \mathrm{~mL})$ at $-78{ }^{\circ} \mathrm{C}$ was added $\operatorname{DIBALH}(0.95 \mathrm{M}$ in hexane, $2.55 \mathrm{~mL}, 2.42 \mathrm{mmol})$. The resultant mixture was stirred at $-78{ }^{\circ} \mathrm{C}$ for $1 \mathrm{~h}$. A solution of $\mathrm{Ac}_{2} \mathrm{O}(0.68 \mathrm{~mL}, 7.26 \mathrm{mmol})$ and DMAP $(0.96 \mathrm{~g}, 7.86 \mathrm{mmol})$ in $\mathrm{CH}_{2} \mathrm{Cl}_{2}(12 \mathrm{~mL})$ was added dropwise over $1 \mathrm{~h}$, and then a solution of pyridine $(0.57 \mathrm{~mL}, 7.26 \mathrm{mmol})$ in $\mathrm{CH}_{2} \mathrm{Cl}_{2}(6 \mathrm{~mL})$ was added over $0.5 \mathrm{~h}$. The mixture was stirred at $-78{ }^{\circ} \mathrm{C}$ for $8 \mathrm{~h}$ and allowed to warm to $0{ }^{\circ} \mathrm{C}$. After being stirred at $0{ }^{\circ} \mathrm{C}$ for $1 \mathrm{~h}$, the reaction mixture was quenched with saturated aqueous $\mathrm{NH}_{4} \mathrm{Cl}$ and saturated aqueous potassium sodium tartrate. The mixture was vigorously stirred until the layers became clear. The solution was diluted with ethyl acetate, washed with brine, dried over $\mathrm{Na}_{2} \mathrm{SO}_{4}$, filtered and concentrated under reduced pressure. The residue was filtered through a plug of silica gel (20\% ethyl acetate/hexanes containing $1 \%$ triethylamine) to afford $\alpha$-acetoxy ether $(0.32 \mathrm{~g})$ as a $3: 1$ mixture of diastereomers, which was used directly in the subsequent reaction.

To a solution of the above $\alpha$-acetoxy ether in $\mathrm{CH}_{2} \mathrm{Cl}_{2}(11 \mathrm{~mL})$ at $-78{ }^{\circ} \mathrm{C}$ were added 2,6-di-tert-butyl-4-methylpyridine (0.46 mL, $2.22 \mathrm{mmol})$, TMSCN $(0.15 \mathrm{~mL}, 1.11 \mathrm{mmol})$ and TMSOTf $(0.30 \mathrm{~mL}, 1.67 \mathrm{mmol})$. The resultant mixture was stirred at $-78^{\circ} \mathrm{C}$ for $30 \mathrm{~min}$ and allowed to warm to $0{ }^{\circ} \mathrm{C}$. After being stirred at $0{ }^{\circ} \mathrm{C}$ for $1 \mathrm{~h}$, the mixture was quenched with triethylamine, filtered and concentrated under reduced pressure. The residue was filtered through a plug of silica gel (30\% ethyl acetate/hexanes) to afford crude $\alpha$-cyano ether $28(0.32 \mathrm{~g})$ as a $3: 1$ mixture of diastereomers: $[\alpha]^{21}{ }_{\mathrm{D}}+5.2\left(c 0.96, \mathrm{CHCl}_{3}\right) ;{ }^{1} \mathrm{H}$ NMR $\left(500 \mathrm{MHz}, \mathrm{CDCl}_{3}\right) \delta 5.87-5.75(\mathrm{~m}, 1.3 \mathrm{H})$, 5.14-4.89 (m, 2.6 H), 4.31 (dd, $J=5.0,8.5 \mathrm{~Hz}, 1 \mathrm{H}), 4.22-4.19(\mathrm{~m}, 0.3 \mathrm{H}), 3.92-3.86(\mathrm{~m}, 2.6 \mathrm{H})$, 3.49-3.44 (m, $1 \mathrm{H}), 3.37-3.32(\mathrm{~m}, 1.6 \mathrm{H}), 3.30-3.22(\mathrm{~m}, 1.3 \mathrm{H}), 3.07-3.05(\mathrm{~m}, 1.3 \mathrm{H}), 2.99-2.90(\mathrm{~m}$, 3.9H), 2.67 (ddd, $J=6.5,6.5,6.5 \mathrm{~Hz}, 1 \mathrm{H}), 2.55(\mathrm{ddd}, J=6.5,6.5,6.5 \mathrm{~Hz}, 0.3 \mathrm{H}), 2.44-2.41(\mathrm{~m}, 0.3 \mathrm{H})$, 2.22-2.19 (m, 1H), 2.12-2.01 (m, 5.2H), 1.94-1.89 (m, 1.3H), 1.86-1.76 (m, 1.3H), 1.72-1.55 (m, 5.2H), 1.43-1.29 (m, 2.6H), 1.27-1.18 (m, 5.2H) 1.09-1.06 (m, 3.9H), $0.83(\mathrm{~m}, 11.7 \mathrm{H}), 7.8(\mathrm{~s}, 7.8 \mathrm{H})$; ${ }^{13} \mathrm{C}$ NMR $\left(125 \mathrm{MHz}, \mathrm{CDCl}_{3}\right) \delta 138.7,118.5,116.1,109.7,85.2,83.9,78.8,76.7,73.6,73.4,67.9$, 64.3, 46.1, 38.0, 32.2, 29.3, 28.2, 25.7 (x 3), 25.7, 25.5, 24.9, 24.0, 22.2, 17.7, -2.0, -2.1 (major isomer); HRMS (FAB) calcd for $\mathrm{C}_{28} \mathrm{H}_{49} \mathrm{NO}_{5} \mathrm{SiNa}\left[(\mathrm{M}+\mathrm{Na})^{+}\right] 530.3278$, found 530.3284.

To a solution of the above $\alpha$-cyano ether in $\mathrm{CH}_{3} \mathrm{CN}(11 \mathrm{~mL})$ was added tetra- $n$-butylammonium 
fluoride $(1.35 \mathrm{~g}, 5.18 \mathrm{mmol})$. The resultant mixture was stirred at $70{ }^{\circ} \mathrm{C}$ for $29 \mathrm{~h}$. The mixture was concentrated under reduced pressure and the residue was purified by column chromatography on silica gel (ethyl acetate) to afford alcohol $29(0.14 \mathrm{~g}, 68 \%$ for the three steps) as a 1.5:1 mixture of diastereomers: $[\alpha]^{21} \mathrm{D}-5.4\left(c 0.81, \mathrm{CHCl}_{3}\right) ;{ }^{1} \mathrm{H} \mathrm{NMR}\left(500 \mathrm{MHz}, \mathrm{CDCl}_{3}\right) \delta 5.89-5.78(\mathrm{~m}, 2.5 \mathrm{H})$, $5.15-4.95(\mathrm{~m}, 5 \mathrm{H}), 4.34(\mathrm{dd}, J=7.0,6.0 \mathrm{~Hz}, 1.5 \mathrm{H}), 4.22(\mathrm{dd}, J=6.5,6.5 \mathrm{~Hz}, 1 \mathrm{H}), 3.92-3.87(\mathrm{~m}, 5 \mathrm{H})$, 3.47 (ddd, $J=11.0,9.5,4.5 \mathrm{~Hz}, 1.5 \mathrm{H}), 3.38-3.32(\mathrm{~m}, 2.5 \mathrm{H}), 3.31-3.23(\mathrm{~m}, 3.5 \mathrm{H}), 3.13-3.10$ (m, $2.5 \mathrm{H}), 3.02-2.99(\mathrm{~m}, 2.5 \mathrm{H}), 2.98-2.93(\mathrm{~m}, 5 \mathrm{H}), 2.68(\mathrm{ddd}, J=15.0,7.0,7,0 \mathrm{~Hz}, 1.5 \mathrm{H}), 2.56$ (ddd, $J=$ 14.0, 7.0, 7.0 Hz, 1H), $2.43(\mathrm{~m}, 1 \mathrm{H}), 2.04(\mathrm{~m}, 1.5 \mathrm{H}), 2.11-2.02(\mathrm{~m}, 9 \mathrm{H}), 1.91-1.81(\mathrm{~m}, 5 \mathrm{H})$, $1.72-1.38(\mathrm{~m}, 21 \mathrm{H}), 1.211-1.205(\mathrm{~m}, 7.5 \mathrm{H}), 1.09(\mathrm{~d}, J=6.5 \mathrm{~Hz}, 4.5 \mathrm{H}), 1.07(\mathrm{~d}, J=7.5 \mathrm{~Hz}, 3 \mathrm{H}) ;{ }^{13} \mathrm{C}$ NMR $\left(125 \mathrm{MHz}, \mathrm{CDCl}_{3}\right) \delta 140.1,138.7,119.7,118.5,116.2,115.4,84.4,84.3,83.8,83.7,78.9,78.9$, 77.6, 76.7 (x 2), 73.7, 71.14, 71.12, 68.1, 67.9 (x 3), 67,8, 64.5, 46.0, 45.9, 38.4, 38.0, 31.8, 31.7, 30.0, 29.24, 29.23, 28.17, 25.5 (x 2), 25.3, 24.9 24.0, 23.6, 21.7, 21.6, 18.1, 17.7; HRMS (FAB) calcd for $\mathrm{C}_{22} \mathrm{H}_{35} \mathrm{NO}_{5}\left[(\mathrm{M}+\mathrm{H})^{+}\right]$394.2593, found 394.2594.

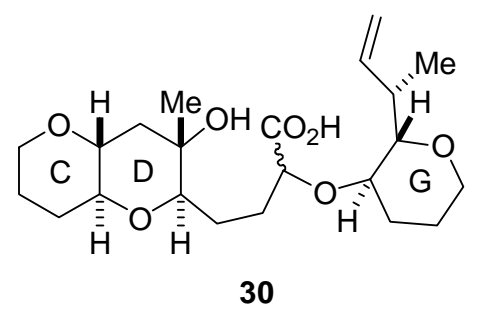

Hydroxy Acid 30. To a solution of alcohol $29(0.14 \mathrm{~g}, 0.35 \mathrm{mmol})$ in ethylene glycol $(3.5 \mathrm{~mL})$ was added $\mathrm{KOH}(0.20 \mathrm{~g}, 3.52 \mathrm{mmol})$. The resultant mixture was stirred at $150{ }^{\circ} \mathrm{C}$ for $14 \mathrm{~h}$. The solution was cooled to room temperature and quenched with $1 \mathrm{M}$ aqueous $\mathrm{HCl}$. The mixture was diluted with $\mathrm{CHCl}_{3}$, washed with $1 \mathrm{M}$ aqueous $\mathrm{HCl}$ and brine. The organic layer was dried over $\mathrm{Na}_{2} \mathrm{SO}_{4}$, filtered and concentrated under reduced pressure. Purification by column chromatography on silica gel $\left(20 \%\right.$ methanol/ $\left.\mathrm{CHCl}_{3}\right)$ afforded hydroxy acid $\mathbf{3 0}(0.14 \mathrm{~g}, 99 \%)$ as a 1:1 mixture of diastereomers: $[\alpha]^{21}{ }_{\mathrm{D}}+0.89\left(c\right.$ 1.12, $\left.\mathrm{CHCl}_{3}\right) ;{ }^{1} \mathrm{H}$ NMR $\left(500 \mathrm{MHz}, \mathrm{CD}_{3} \mathrm{OD}\right) \delta 5.90-5.81(\mathrm{~m}, 2 \mathrm{H})$, $5.09-4.95(\mathrm{~m}, 4 \mathrm{H}), 4.05(\mathrm{dd}, J=7.5,4.5 \mathrm{~Hz}, 1 \mathrm{H}), 3.90(\mathrm{dd}, J=5.5,5.5 \mathrm{~Hz}, 1 \mathrm{H}), 3.85-3.82(\mathrm{~m}, 4 \mathrm{H})$, $3.40-3.23(\mathrm{~m}, 9 \mathrm{H}), 3.18$ (ddd, $J=9.0,4.0 \mathrm{~Hz} 1 \mathrm{H}), 3.12-2.91(\mathrm{~m}, 8 \mathrm{H}), 2.84$ (ddd, $J=14.5,7.0,7.0 \mathrm{~Hz}$, $1 \mathrm{H}), 2.74(\mathrm{ddd}, J=14.0,7.0,7.0 \mathrm{~Hz}, 1 \mathrm{H}), 2.28-2.26(\mathrm{~m}, 1 \mathrm{H}), 2.17-2.14(\mathrm{~m}, 1 \mathrm{H}), 2.02-1.92(\mathrm{~m}, 7 \mathrm{H})$, $1.86-1.76(\mathrm{~m}, 3 \mathrm{H}), 1.69-1.26(\mathrm{~m}, 18 \mathrm{H}), 1.14(\mathrm{~s}, 6 \mathrm{H}), 1.08-1.06(\mathrm{~m}, 6 \mathrm{H}) ;{ }^{13} \mathrm{C} \mathrm{NMR}(125 \mathrm{MHz}$, $\left.\mathrm{CD}_{3} \mathrm{OD}\right) \delta 178.5,176.9,141.1,141.0,116.1,115.8,86.2,86.0,85.8,85.5,80.2,80.2,79.8,78.3$ (x 2), 77.9, 77.4, 75.4, 71.6, 71.6, 68.8 (x 2), 68.8, 68.6, 46.7, 46.7, 39.5, 38.9, 32.2, 32.2, 31.1, 30.5, 30.33, $30.31,26.7$ (x 2), 26.5, 26.2, 25.6, 25.4, 21.6, 21.5, 18.9, 18.6; HRMS (FAB) calcd for $\mathrm{C}_{22} \mathrm{H}_{36} \mathrm{O}_{7} \mathrm{SiNa}$ $\left[(\mathrm{M}+\mathrm{Na})^{+}\right]$435.2359, found 435.2365. 

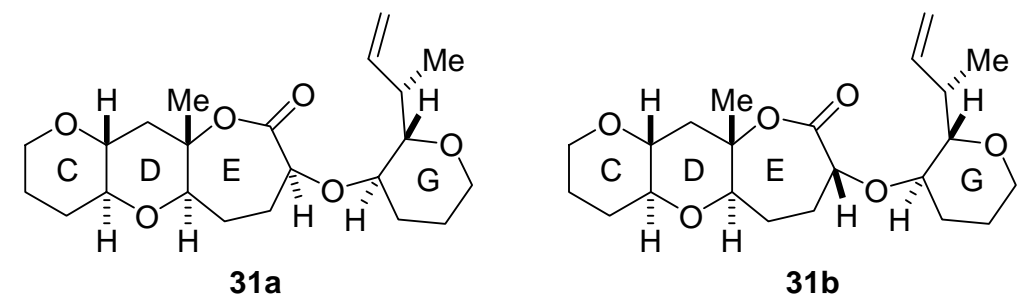

Lactones 31a and 31b. To a solution of hydroxy acid $\mathbf{3 0}(0.44 \mathrm{~g}, 1.07 \mathrm{~mol})$ in THF/toluene $(1: 1$, $\mathrm{v} / \mathrm{v}, 22 \mathrm{~mL})$ at $0{ }^{\circ} \mathrm{C}$ were added triethylamine $(0.30 \mathrm{~mL}, 2.13 \mathrm{mmol})$ and 2,4,6-trichlorobenzoyl chloride $(0.25 \mathrm{~mL}, 1.60 \mathrm{mmol})$. The resultant mixture was stirred at room temperature for $2 \mathrm{~h}$ and then diluted with toluene $(44 \mathrm{~mL})$. This mixture was added dropwise to a refluxing solution of DMAP $(0.65 \mathrm{~g}, 5.33 \mathrm{mmol})$ in toluene $(107 \mathrm{~mL})$ over a period of $1.5 \mathrm{~h}$. The reaction mixture was cooled to room temperature and concentrated under reduced pressure. Purification by column chromatography on silica gel (10-20\% ethyl acetate/hexanes) afforded lactones 31a $(0.16 \mathrm{~g}, 38 \%)$ as a colorless oil and 31b $(0.17 \mathrm{~g}, 40 \%)$ as a solid. 31a: $[\alpha]^{21}{ }_{\mathrm{D}}-49.5\left(c 0.55, \mathrm{CHCl}_{3}\right) ;{ }^{1} \mathrm{H} \mathrm{NMR}\left(500 \mathrm{MHz}, \mathrm{CDCl}_{3}\right) \delta$ $5.80(\mathrm{ddd}, J=18.5,10.5,9.0 \mathrm{~Hz}, 1 \mathrm{H}), 5.07(\mathrm{~d}, J=16.5 \mathrm{~Hz}, 1 \mathrm{H}), 5.05(\mathrm{~d}, J=10.5 \mathrm{~Hz}, 1 \mathrm{H}), 4.40(\mathrm{~d}, J$ $=4.0 \mathrm{~Hz}, 1 \mathrm{H}), 3.91-3.85(\mathrm{~m}, 2 \mathrm{H}), 3.43-3.31(\mathrm{~m}, 3 \mathrm{H}), 3.24(\mathrm{ddd}, J=11.0,11.0,2.5 \mathrm{~Hz}, 1 \mathrm{H})$, 3.04-2.95 (m, 3H), 2.65 (ddd, $J=14.0,7.0,7.0 \mathrm{~Hz}, 1 \mathrm{H}), 2.28(\mathrm{dd}, J=12.5,8.5 \mathrm{~Hz}, 1 \mathrm{H}), 2.17(\mathrm{~m}, 1 \mathrm{H})$, 2.11-2.02 (m, 2H), 1.95-1.89 (m, 1H), 1.80-1.76 (m, 2H) 1.73-1.66 (m, 5H), 1.63-1.49 (m, 3H), $1.45-1.34(\mathrm{~m}, 2 \mathrm{H}), 1.07(\mathrm{~d}, J=7.0 \mathrm{~Hz}, 3 \mathrm{H}) ;{ }^{13} \mathrm{C} \mathrm{NMR}\left(125 \mathrm{MHz}, \mathrm{CDCl}_{3}\right) \delta 171.1,138.9,116.1,84.1$, 82.9, 82.4, 79.0, 78.5, 76.5, 76.4, 67.9, 67.6, 45.1, 37.7, 30.1, 29.1, 27.7, 25.4, 25.1, 24.8, 20.2, 18.1; HRMS (FAB) calcd for $\mathrm{C}_{22} \mathrm{H}_{35} \mathrm{O}_{6}\left[(\mathrm{M}+\mathrm{H})^{+}\right] \quad 395.2434$, found 395.2434.

31b: $[\alpha]^{21}{ }_{\mathrm{D}}-13.9\left(c 0.83, \mathrm{CHCl}_{3}\right) ;{ }^{1} \mathrm{H} \mathrm{NMR}\left(500 \mathrm{MHz}, \mathrm{CDCl}_{3}\right) \delta 5.95(\mathrm{ddd}, J=19.0,9.0,9.0 \mathrm{~Hz}$, $1 \mathrm{H}), 5.05(\mathrm{dd}, J=10.0,1.5 \mathrm{~Hz}, 1 \mathrm{H}), 5.02(\mathrm{~d}, J=17.0 \mathrm{~Hz}, 1 \mathrm{H}), 4.12(\mathrm{dd}, J=11.0,1.5 \mathrm{~Hz}, 1 \mathrm{H})$, 3.91-3.85 (m, 2H), 3.37-3.32 (m, 2H), 3.25 (ddd, $J=13.5,11.5,2.5 \mathrm{H}, 1 \mathrm{H}), 3.11-3.01(\mathrm{~m}, 3 \mathrm{H}), 2.96$ (ddd, $J=12.0,9.5,4.0 \mathrm{~Hz}, 1 \mathrm{H}), 2.63(\mathrm{ddd}, J=15.0,7.5,7.5 \mathrm{~Hz}, 1 \mathrm{H}), 2.37-2.35(\mathrm{~m}, 1 \mathrm{H}), 2.26$ (dd, $J=$ 12.0, $3.5 \mathrm{~Hz}, 1 \mathrm{H}), 2.04-2.02(\mathrm{~m}, 3 \mathrm{H}), 1.85-1.76(\mathrm{~m}, 3 \mathrm{H}) 1.73-1.69(\mathrm{~m}, 2 \mathrm{H}), 1.64-1.61(\mathrm{~m}, 1 \mathrm{H})$, $1.58-1.45(\mathrm{~m}, 5 \mathrm{H}), 1.43-1.35(\mathrm{~m}, 1 \mathrm{H}), 1.09(\mathrm{~d}, J=6.5 \mathrm{~Hz}, 3 \mathrm{H}) ;{ }^{13} \mathrm{C} \mathrm{NMR}\left(125 \mathrm{MHz}, \mathrm{CDCl}_{3}\right) \delta 172.8$, 140.7, 115.2, 84.5, 80.9, 80.8, 79.1, 79.0, 77.6, 76.3, 68.0, 67.9, 45.1, 38.6, 30.4, 29.03, 29.01, 27.7, 25.7, 25.4, 19.8, 18.7; HRMS (FAB) calcd for $\mathrm{C}_{22} \mathrm{H}_{35} \mathrm{O}_{6}\left[(\mathrm{M}+\mathrm{H})^{+}\right]$395.2434, found 395.2433.

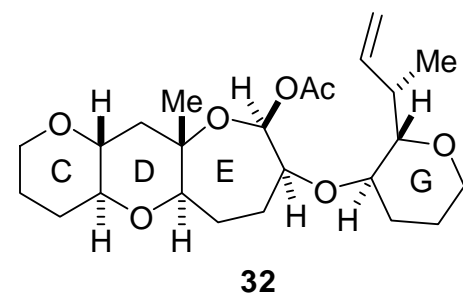

Acetate 32. To a solution of lactone 31a $(0.15 \mathrm{~g}, 0.39 \mathrm{~mol})$ in $\mathrm{CH}_{2} \mathrm{Cl}_{2}(7.7 \mathrm{~mL})$ at $-78{ }^{\circ} \mathrm{C}$ was added DIBALH $(0.95 \mathrm{M}$ in hexane $1.64 \mathrm{~mL}, 1.55 \mathrm{mmol})$. The resultant mixture was stirred at $-78{ }^{\circ} \mathrm{C}$ 
for $1 \mathrm{~h}$. A solution of $\mathrm{Ac}_{2} \mathrm{O}(0.44 \mathrm{~mL}, 4.64 \mathrm{mmol})$ and DMAP $(0.61 \mathrm{~g}, 5.02 \mathrm{mmol})$ in $\mathrm{CH}_{2} \mathrm{Cl}_{2}(7.7 \mathrm{~mL})$ was added dropwise over $40 \mathrm{~min}$, and then a solution of pyridine $(0.38 \mathrm{~mL}, 4.64 \mathrm{mmol})$ in $\mathrm{CH}_{2} \mathrm{Cl}_{2}$ $(3.9 \mathrm{~mL})$ was added over $20 \mathrm{~min}$. The resulting mixture was stirred at $-78^{\circ} \mathrm{C}$ for $13 \mathrm{~h}$ and allowed to warm to $0{ }^{\circ} \mathrm{C}$. After being stirred at $0{ }^{\circ} \mathrm{C}$ for $1 \mathrm{~h}$, the reaction mixture was quenched with saturated aqueous $\mathrm{NH}_{4} \mathrm{Cl}$ and saturated aqueous potassium sodium tartrate, and vigorously stirred until the layers became clear. The mixture was diluted with $\mathrm{CH}_{2} \mathrm{Cl}_{2}$, and washed with brine. The organic layer was dried over $\mathrm{Na}_{2} \mathrm{SO}_{4}$, filtered and concentrated under reduced pressure. Purification by column chromatography on silica gel (30\% ethyl acetate/hexanes) afforded acetate $32(0.16 \mathrm{~g}, 93 \%)$ as a colorless oil: $[\alpha]^{21}{ }_{\mathrm{D}}-26.4\left(c\right.$ 0.73, $\left.\mathrm{CHCl}_{3}\right) ;{ }^{1} \mathrm{H}$ NMR $\left(500 \mathrm{MHz}, \mathrm{CDCl}_{3}\right) \delta$ 5.96-5.89 (m, 2H), 5.02-4.98 (m, 2H), 3.88-3.86 (m, 2H), 3.77-3.56 (m, 1H), 3.36-3.30 (m, 2H), 3.27-3.21 (m, 2H), $3.06(\mathrm{dd}, J=9.5,1.0 \mathrm{~Hz}, 1 \mathrm{H}), 3.01-2.98(\mathrm{~m}, 2 \mathrm{H}), 2.89(\mathrm{ddd}, J=7.5,7.5,7.5 \mathrm{~Hz}, 1 \mathrm{H}), 2.07-2.00(\mathrm{~m}$, $8 \mathrm{H}), 1.97-1.85(\mathrm{~m}, 2 \mathrm{H}), 1.72-1.50(\mathrm{~m}, 4 \mathrm{H}), 1.47-1.37(\mathrm{~m}, 3 \mathrm{H}), 1.33(\mathrm{~s}, 3 \mathrm{H}), 1.08(\mathrm{~d}, J=7.5 \mathrm{~Hz}, 3 \mathrm{H})$; ${ }^{13} \mathrm{C} \mathrm{NMR}\left(125 \mathrm{MHz}, \mathrm{CDCl}_{3}\right) \delta 169.2,140.2,115.2,91.7,85.2,83.2,79.9,77.2,76.7,76.2,74.3$, $67.90,67.85,43.0,37.2,31.4,29.4,28.9,25.6,25.5,24.4,21.2,20.8,18.1$; HRMS (FAB) calcd for $\mathrm{C}_{24} \mathrm{H}_{38} \mathrm{O}_{7} \mathrm{Na}\left[(\mathrm{M}+\mathrm{Na})^{+}\right]$461.2515, found 461.2519.

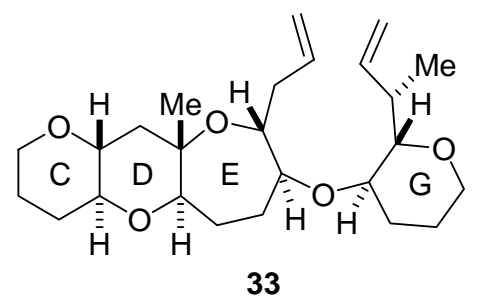

Diene 33. To a suspension of acetate $32(50.0 \mathrm{mg}, 0.11 \mathrm{mmol})$ and $4 \AA$ molecular sieves in $\mathrm{CH}_{3} \mathrm{CN}(1.2 \mathrm{~mL})$ at $-40{ }^{\circ} \mathrm{C}$ was added allyltrimethylsilane $(55.0 \mu \mathrm{L}, 0.34 \mathrm{mmol})$. After $5 \mathrm{~min}$, $\mathrm{BF}_{3}$. OEt $(4 \mu \mathrm{L}, 34.0 \mu \mathrm{mol})$ was added. The resultant mixture was stirred at $-40{ }^{\circ} \mathrm{C}$ for $2 \mathrm{~h}$ and allowed to warm to $0{ }^{\circ} \mathrm{C}$. After being stirred at $0{ }^{\circ} \mathrm{C}$ for $2 \mathrm{~h}$, the reaction mixture was quenched with triethylamine, filtered and concentrated under reduced pressure. Purification by column chromatography on silica gel (10\% ethyl acetate/hexanes) afforded diene $\mathbf{3 3}(31.6 \mathrm{mg}, 67 \%)$ as a colorless oil: $[\alpha]^{21}{ }_{\mathrm{D}}+2.9\left(c\right.$ 1.30, $\left.\mathrm{CHCl}_{3}\right) ;{ }^{1} \mathrm{H}$ NMR $\left(500 \mathrm{MHz}, \mathrm{CDCl}_{3}\right) \delta$ 5.91-5.76 (m, 2H), 5.05-4.99 (m, 4H), 3.89-3.84 (m, 2H), $3.77(\mathrm{ddd}, J=7.5,7.5,2.0 \mathrm{~Hz}, 1 \mathrm{H}), 3.51(\mathrm{dd}, J=2.5,2.5 \mathrm{~Hz}$, $1 \mathrm{H}), 3.34(\mathrm{ddd}, J=11.5,11.5,4.0 \mathrm{~Hz}, 1 \mathrm{H}), 3.23(\mathrm{ddd}, J=11.0,11.0,2.5 \mathrm{~Hz}, 1 \mathrm{H}), 3.11-2.95(\mathrm{~m}, 5 \mathrm{H})$, 2.66 (ddd, $J=15.0,5.0,5.0 \mathrm{~Hz}, 1 \mathrm{H}), 2.23-2.21(\mathrm{~m}, 2 \mathrm{H}), 2.10-2.02(\mathrm{~m}, 2 \mathrm{H}), 1.94(\mathrm{dd}, J=11.0,3.5 \mathrm{~Hz}$, 1H) $1.84(\mathrm{~m}, 1 \mathrm{H}), 1.78-1.67(\mathrm{~m}, 3 \mathrm{H}), 1.58-1.51(\mathrm{~m}, 5 \mathrm{H}), 1.46-1.38(\mathrm{~m}, 1 \mathrm{H}), 1.35-1.27(\mathrm{~m}, 4 \mathrm{H}), 1.08$ $(\mathrm{d}, J=7.0 \mathrm{~Hz}, 3 \mathrm{H}) ;{ }^{13} \mathrm{C} \mathrm{NMR}\left(125 \mathrm{MHz}, \mathrm{CDCl}_{3}\right) \delta 139.7,135.4,116.8,115.2,85.6,84.8,80.5,79.2$, 77.6, 77.2, 76.0, 74.3, 68.0, 67.9, 45.1, 41.2, 37.7, 31.1, 29.5, 27.1, 25.7, 25.4, 23.7, 18.4, 16.0; HRMS (FAB) calcd for $\mathrm{C}_{25} \mathrm{H}_{41} \mathrm{O}_{5} \mathrm{Si}\left[(\mathrm{M}+\mathrm{H})^{+}\right]$421.2954, found 421.2959. 


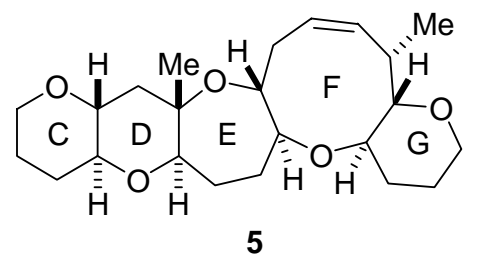

CDEFG Ring System 5. To a solution of diene $33(6.70 \mathrm{mg}, 15.9 \mu \mathrm{mol})$ in $\mathrm{CH}_{2} \mathrm{Cl}_{2}(3.2 \mathrm{~mL})$ was added Grubbs' catalyst $34(3.4 \mathrm{mg}, 25.0 \mu \mathrm{mol})$. The resultant mixture was stirred at $40{ }^{\circ} \mathrm{C}$ for $20 \mathrm{~h}$. The reaction mixture was cooled to $0{ }^{\circ} \mathrm{C}$, quenched with triethylamine (1 drop), and concentrated under reduced pressure. Purification by column chromatography on silica gel (10\% ethyl acetate/hexanes) afforded CDEFG ring system $5(6.10 \mathrm{mg}, 98 \%)$ as a colorless oil: $[\alpha]^{21}{ }_{\mathrm{D}}-54.3(c$ $\left.1.00, \mathrm{CHCl}_{3}\right) ;{ }^{1} \mathrm{H}$ NMR $\left(500 \mathrm{MHz}, \mathrm{CDCl}_{3}\right) \delta 5.71$ (ddd, $\left.J=11.0,5.0,5.0 \mathrm{~Hz}, 1 \mathrm{H}\right), 5.42(\mathrm{dd}, J=11.0$, $11.0 \mathrm{~Hz}, 1 \mathrm{H}), 3.86(\mathrm{~m}, 2 \mathrm{H}), 3.80(\mathrm{ddd}, J=10.5,3.0,3.0 \mathrm{~Hz}, 1 \mathrm{H}), 3.34(\mathrm{ddd}, J=11.0,11.0,4.5 \mathrm{~Hz}$, $1 \mathrm{H}), 3.24-3.12(\mathrm{~m}, 3 \mathrm{H}), 3.10-3.05(\mathrm{~m}, 2 \mathrm{H}), 3.03-2.98(\mathrm{~m}, 2 \mathrm{H}), 2.93$ (ddd, $J=11.0,11.0,3.5 \mathrm{~Hz}, 1 \mathrm{H})$, 2.78 (ddd, $J=14.5,14.5,3.5 \mathrm{~Hz}, 1 \mathrm{H}), 2.14-1.92(\mathrm{~m}, 5 \mathrm{H}), 1.79-1.65(\mathrm{~m}, 4 \mathrm{H}), 1.63-1.50(\mathrm{~m}, 4 \mathrm{H})$, $1.45-1.34(\mathrm{~m}, 2 \mathrm{H}), 1.18(\mathrm{~s}, 3 \mathrm{H}), 1.00(\mathrm{~d}, J=6.5 \mathrm{~Hz}, 3 \mathrm{H}) ;{ }^{13} \mathrm{C} \mathrm{NMR}\left(125 \mathrm{MHz}, \mathrm{CDCl}_{3}\right) \delta 134.0,126,6$, 84.8, 84.0, 83.9, 82.2, 79.1, 77.0, 75.4, 75.3, 68.7, 67.9, 45.0, 32.3, 32.2, 32.1, 31.4, 29.4, 26.2, 25.6, 24.5, 16.6, 15.5; HRMS (FAB) calcd for $\mathrm{C}_{23} \mathrm{H}_{37} \mathrm{O}_{5}\left[(\mathrm{M}+\mathrm{H})^{+}\right]$393.2641, found 393.2644. 